УДК 373.3.016:81(07)

DOI https://doi.org/10.32782/apv/2021.4.20

\title{
Тамара ШЕВЧУК
}

кандидат філологічних наук, дочент кафедри теорії $i$ методик початкової освіти, Рівненський державний гуманітарний університет, вул. Степана Бандери, 12, м. Рівне, Украӥна, 33028 ORCID: 0000-0003-4094-7744

\section{Ольга ТКАЧУК}

старший викладач кафедри теорії і методик початкової освіти, Рівненський державний гуманітарний університет, вул. Степана Бандери, 12, м. Рівне, Україна, 33028

ORCID: 0000-0002-2391-5102

Бібліографічний опис статті: Шевчук, Т., Ткачук, О. (2021). Реалізація змістової лінії «Досліджуємо мовні явища» у процесі вивчення розділу «Будова слова» в початковій школі. Acta Paedagogica Volynienses, 4, 131-138, doi: https://doi.org/10.32782/apv/2021.4.20

\section{РЕАЛІЗАЦІЯ ЗМІСТОВОЇ ЛІНІЇ «ДОСЛІДЖУСМО МОВНІ ЯВИЩА» У ПРОЦЕСІ ВИВЧЕННЯ РОЗДІЛУ «БУДОВА СЛОВА» В ПОЧАТКОВІЙ ШКОЛІ}

У статті висвітлено сутність змістової лінії «Досліджуємо мовні явища» у процесі вивчення розділу «Будова слова», лінгводидактичні аспекти опраџювання изього розділу в школі. Розкрито значущість і обтрунтовано актуальність вивчення иієї змістової лінії, спрямованої на дослідження учнями морфемної будови слова та елементів словотвору; зазначено ї̈ місие в сучасних лінгвометодичних дослідженнях.

Проаналізовано зміст програмного матеріалу, взаємозв'язок будови слова та елементів словотвору з іншими розділами украӥнської мови, щзо вивчаються в початковій школі. Акцентовано увагу на значимості оволодіння здобувачами початкової освіти розділу «Будова слова» для свідомого засвоєння виучуваних орфографічних правил, у результаті чого підвищуються правописна грамотність, розуміння структури слова і прочесів його утворення, загальний мовно-мовленнєвий розвиток школярів, формується логічне мислення, вдосконалюється культура мовлення; діти набувають аналітико-конструктивних умінь $і$ навичок, які надалі будуть застосовувати на практиці.

Досліджено стан проблеми в шкільній практиці навчання. Досвід учителів м. Рівне та Рівненської області свідчить, щцо під час опращювання цьього розділу треба навчати школярів усвідомлювати походження окремих слів, а також встановлювати їх взаємозв'язок із лексичним значенням та будовою. Підкреслено важливість попередження типових учнівських помилок. Школярі звертають увагу на матеріальну оболонку слова, часто не знаючи його значення. Аналізуючи слова, вони враховують лише їх зовнішне оформлення і не розуміють ролі закінчення - вираження граматичного значення слова; в них не сформовані поняття «спільнокореневі слова» $i$ «орми одного і того ж слова»; додаючи до кореня префікс або суфікс, а до суфікса-закінчення, школярі не помічають чергувань звуків у коренях слів.

Проаналізовано розділ «Будова слова»у чинних підручниках «Українська мова та читання» для учнів 3-4 класів, авторами яких є М.С. Вашуленко, Н.А. Васильківська, С.Г. Дубовик. Підкреслено, щяо програмовий матеріал щзодо будови слова та елементів словотворення, який опрацьовується на уроках украӥнської мови та читання в початкових класах, є базовим для свідомого оволодіння мовою в середніх та старших класах.

Ключові слова: змістова лінія "Досліджуємо мовні явища», морфемна будова, словотвір, корінь, префікс, суфікс, закінчення, споріднені слова.

\section{Tamara SHEVCHUK}

Candidate of Philological Sciences, Associate Professor at the Department of Theory and Methods of Primary Education, Rivne State University of Humanities, Stepan Bandera str., 12, Rivne, Ukraine, 33000

ORCID: 0000-0001-5284-0296

\section{Olga TKACHUK}

Senior Lecturer at the Department of Theory and Methods of Primary Education, Rivne State University of Humanities, Stepan Bandera str., 12, Rivne, Ukraine, 33000

ORCID: 0000-0002-2391-5102 
To cite this article: Shevchuk, T., Tkachuk, O. (2021). Realizasiya zmistovoyi liniyi «Doslidzuyemo movni yavyshcha»u protsesi vyvchenna rozdilu «Budova slova v pochatkoviiy shkoli» [Implementation of the content line «We explore languages phenomena» in the process of studying the section «Structural words» in primary school]. Acta Paedagogica Volynienses, 4, 131-138, doi: https://doi.org/10.32782/apv/2021.4.20

\section{IMPLEMENTATION OF THE CONTENT LINE “WE EXPLORE LANGUAGES PHENOMENA” IN THE PROCESS OF STUDYING THE SECTION “STRUCTURAL WORDS” IN PRIMARY SCHOOL}

The article highlights the essence of the content line "Exploring language phenomena" in the process of studying the section "Word structure", linguodidactic aspects of the study of this section in school. The significance and substantiation of the relevance of the study of this semantic line, aimed at the study by students of the morpheme structure of the word and the elements of word formation, is revealed and its place in modern linguistic-methodica lresearches is noted.

The content of the program material, the relationship of word structure and word formation elements with other sections of the Ukrainian language studied in primary school are analyzed. Emphasis is placed on the importance of mastering by primary school students the section "Word structure" for conscious mastering of learned spelling rules, resulting in increased spelling literacy, understanding of word structure and processes of its formation, general language and speech development ofstudents, logical thinking is formed, culture is improved; children acquire analytical and constructive skills that will be applied in practice in the future. The state of the problem in school practice is studied.

The experience of teachers in Rivne and Rivnenska oblast shows that in developing this section it is necessary to teach students to understand the origin of individual words, as well as to establish their relationship with the lexical meaning and structure. The importance of preventing typical student mistakes is emphasized. Students pay attention to the material shell of the word, often not understanding the meaning itself. While analyzing words, they take into account only their external design, and do not understand the role of the ending-the expression of the grammatical meaning of the word; they do not form the concepts of "common root words" and "forms of the same word"; while adding a prefix or suffix to the root and an ending to the suffix, they do not notice the alternation of sounds in the roots of words.

The section "Word structure" in the current textbooks "Ukrainian language and reading" for students of grades 3-4, authored by M. Vashulenko, N. Vasylkivska, S. Dubovyk is analyzed. It is emphasized that the program material on word structure and word formation elements, which is developed in Ukrainian language and reading lessons in primary school, is the basis for conscious mastery of the language in middle and senior classes.

Key words: semantic line "Investigating linguistic phenomena", morpheme structure, word formation, root, prefix, suffix, ending, related words.

Актуальність проблеми. Змістова лінія «Досліджуємо мовні явища» - одна 3 ліній вивчення мовно-літературної освітньої галузі, визначена типовими освітніми програмами Нової української школи (як Р. Шияна, так і О. Савченко). Ця лінія передбачає засвоєння мовно-мовленнєвого матеріалу учнями початкових класів через дослідження лінгвістичних понять та явищ у процесі активної розумової діяльності - спостереження, аналізу, порівняння, виділення головного, встановлення причинно-наслідкових зв'язків, узагальнення, спростування, вираження власних думок, підбиття підсумків тощо, що забезпечуватиме інтелектуально мовно-мовленнєвий розвиток школярів та їхні усвідомлені й міцні знання (розуміння функціональної ролі та значення префіксу, кореня, суфікса, закінчення; правильне і точне вживання в мовленні лексичних одиниць із похідною основою тощо), сформує мовне чуття, підвищить ефективність навчання учнів.
Реалізація змістової лінії «Досліджуємо мовні явища» в процесі вивчення розділу «Будова слова» сприятиме виконанню головної мети вивчення української мови: як результат розвитку мислення і мовлення учнів, усвідомлення структури слова, елементів словотвірної системи, відбуватиметься загальний розвиток особистості здобувача початкової освіти, його здатність спілкуватися українською мовою.

Аналіз останніх досліджень і публікацій. Безпосередньо проблемі реалізації змістової лінії «Досліджуємо мовні явища» присвячені лише окремі, хоч і доволі просторові, статті та методичні рекомендації в різних педагогічних виданнях, оскільки тільки з 2018 року ця змістова лінія була передбачена типовими освітніми програмами НУШ авторів Р. Шияна та О. Савченко.

К.І. Пономарьова, аналізуючи усі змістові лінії початкового курсу мовно-літературної освіти в 2-му класі, акцентує на реалізації змістової лінії «Досліджуємо мовні явища», 
окреслює орієнтовний зміст завдань і різних видів вправ, представляє методику застосування цієї лінії у процесі навчання української мови (Пономарьова). М.С. Вашуленко і С.Г. Дубовик висвітлюють проблеми формування в учнів початкових класів дослідницьких умінь на матеріалі програмового курсу української мови (Вашуленко, Дубовик, 2020). М.С. Вашуленко, розкриваючи методику навчання інтегрованого курсу «Українська мова» у 1-2 класах закладів загальної середньої освіти на засадах компетентнісного підходу, надає методичні рекомендації щодо втілення в освітній процес змістової лінії «Досліджуємо мовні явища» (Вашуленко, 2019). О.А. Гордієнко описує актуальні проблеми вивчення морфемної будови слова та елементів словотвору, пропонує спеціальні вправи для уроків української мови в початкових класах, наголошуючи на їх розвивальній спрямованості (Гордієнко, 2014).

Л.А. Бісовецька звертає увагу на комплексний підхід до вивчення слова, який реалізується шляхом виконання вправ різнорівневого мовного характеру, аргументує доцільне поєднання аналізу і синтезу в процесі вивчення будови слова та елементів словотвору, зазначає, що мовні факти і структури засвоюються під час аналітико-синтетичної діяльності учнів, наводить приклад комплексних завдань до тексту казки Марійки Луговик і Івана Малковича «Вовченятко, яке запливло далеко в море» (Бісовецька, 2016). Проблеми, які стосуються практичного володіння словотворчими засобами мови школярами з тяжкими порушеннями мовлення, досліджені О.М. Гриненко. Учена підкреслює, що розвиток мовлення учнів полягає не лише в кількісному збагаченні їх словника, а й в глибокому усвідомленні значень кожного слова, чому сприяє засвоєння основних понять розділу «Будова слова» (Гриненко, 2014).

Результатом пошуків учених стала розробка системи вивчення морфемної будови слова та елементів словотвору на уроках мови в початкових класах, теоретичне обгрунтування методичних рекомендацій щодо організації систематичних словотворчих вправ. Найчастіше це синтетичні завдання, добір споріднених слів, конструювання похідних лексичних одиниць із допомогою різних словотворчих засобів.

Мета дослідження - висвітлити сутність та реалізацію змістової лінії «Досліджуємо мовні явища» у процесі вивчення розділу «Будова слова».

Виклад основного матеріалу дослідження. Традиційний урок, побудований за схемою «опитування - пояснення - закріплення», не враховує закономірностей розвитку розумової діяльності школярів, а отже, не гарантує інтелектуального розвитку учнів.

Успішність навчання й розвиток школярів залежать значною мірою від включення їх в активну розумову діяльність. Численні дослідження, проведені в нашій країні відомими вченими психологами і педагогами Л.В. Занковим, Г.О. Люблінською, Н.О. Менчинською, M.M. Скаткіним, М.I. Махмутовим та іншими, засвідчили, що тільки активна діяльність самого школяра є запорукою його успішного розвитку.

Змістова лінія «Досліджуємо мовні явища» передбачає вивчення мовних явищ і понять та формування свідомих орфоепічних, орфографічних, лексичних, словотвірних, морфологічних, синтаксичних, стилістичних умінь. Ця змістова лінія у програмі, автором якої $€$ Р. Шиян, доповнена завданнями на опанування виражальних засобів художніх текстів, що сприятиме розвитку індивідуального стилю мовлення.

Усвідомлене засвоєння школярами елементарних знань про будову слова і правописних норм здійснюється в процесі дослідження (спостереження, аналізу, порівняння, узагальнення, встановлення причинно-наслідкових зв'язків тощо, тобто в процесі активної розумової діяльності) окремих структурних частин слова та словотвірних явищ.

3 огляду на мету й завдання вивчення української мови в школі вчення про будову слова належить до фундаментальних знань, які необхідні, насамперед, для виховання в школярів лінгвістичного ставлення до мови, тобто ясного, усвідомленого розуміння ними зв'язків між відтінками змісту й мовними формами їх вираження. Відомості про склад слова й способи творення нових лексем проходять через більшість розділів і тем курсу, вони поглиблюються в усіх наступних класах.

Програма 3 мови побудована на основі концентричного принципу розміщення матеріалу, при якому одна і та ж тема вивчається протягом кількох років із поступовим ускладненням. Концентричне розташування матеріалу 
дає змогу розчленовувати складні граматичні поняття на елементи та кожен відпрацьовувати окремо. У результаті поступово збільшується кількість зв'язків, що лежать в основі поняття, розширюється мовна й мовленнєва база для формування вмінь і навичок. Концентризм програми також створює умови для постійного повторення раніше засвоєного матеріалу.

Відповідно до змісту розділу «Будова слова» перед учителем стоять такі завдання:

a) сформувати в учнів поняття про частини слова;

б) забезпечити усвідомлення молодшими школярами ролі частин слова;

в) розвивати вміння здійснювати розбір слів за будовою;

г) сформувати в учнів уміння розрізняти форми слова і спільнокореневі

слова;

г) забезпечити практичне оволодіння морфологічними способами творення слів (без називання термінів);

д) сприяти збагаченню словника учнів.

У вказаних завданнях, як і у змісті чинної програми з української мови, передбачено реалізацію принципу наступності та перспективності в процесі викладання матеріалу розділу «Будова слова».

У процесі вдосконалення змісту розділу «Будова слова», на нашу думку, важливо передбачити:

- проведення вже 31 класу морфемної та словотворчої роботи пропедевтичного характеру, виховуючи уявлення, набуті дітьми в дошкільний період;

- посилення уваги до семантики афіксів під час вивчення структури слова;

- засвоєння дітьми взаємозв'язку у слові морфемного складу та лексичного значення;

- удосконалення комунікативних умінь школярів.

Урахування вищевказаних аспектів у навчанні української мови учнів 1-4 класів, на наш погляд, забезпечуватиме іiі якісне засвоєння.

Проаналізувавши матеріал підручників «Українська мова та читання» (перші частини) для учнів 3-4 класів, авторами яких є М.С. Вашуленко, Н.А. Васильківська, С.Г. Дубовик, ми виділили 114 завдань, серед них: 35 словотворчих вправ (31\%), 53 орфографічних (46\%),
26 лексичних (23\%). Проте цей розподіл вважаємо умовним, враховуючи комплексний підхід до розгляду лінгводидактичних явищ.

Види завдань до вправ продумані так, щоб у полі зору учнів були всі головні питання теми, й складені так, щоб закріпити вивчений на уроці матеріал, повторити те, що вивчалося раніше. Систематичне повторення сприяє глибокому засвоєнню учнями теоретичних знань, виробленню в них навичок грамотного письма.

У завданнях до вправ знаходять висвітлення такі етапи засвоєння мови: сприйняття й осмислення нового матеріалу; закріплення та поглиблення знань, формування визначених програмою умінь і навичок; самостійне застосування теоретичних знань під час виконання практичних завдань. Вправи спрямовані на розвиток різноманітних видів пам'яті, активізацію діяльності учнів і зумовлюють виконання завдань, що передбачають, з одного боку, формування активних мовленнєвих навичок (репродуктивні вправи), з іншого - організацію спостережень, аналізу, підведення до висновку щодо закономірності (рецептивні вправи). На цій підставі завдання до вправ можна поділити на дві групи:

1) мовні, або, за іншою термінологією, тренувальні, підготовчі, на основі яких вивчаються власне граматичні категорії, значення та форми;

2) мовленнєві, творчі, зо допомогою яких опрацьовуються навички вживання відповідних граматичних закономірностей у мовленні.

Мовні вправи умовно поділимо на три групи:

a) аналіз заданого мовного матеріалу (вправи, побудовані на використанні ізольованих слів або словосполучень) - аналітичні;

б) конструювання мовного матеріалу за цими параметрами (самостійне придумування) синтетичні;

в) зміна заданого мовного матеріалу (у вправах пропонується змінювати форму головних слів) - аналітико-синтетичні.

У таких вправах у центрі уваги знаходиться слово як граматична одиниця, але в школярів необхідно не тільки створювати суму знань із граматики, але й формувати навички правильного мовлення. Тому перевага має віддаватися вправам зі зміною заданого мовного матеріалу та його самостійним конструюванням. Вправи цих двох груп безпосередньо стимулюють практику активного формотворення слів, на відміну від аналізу готового мовного матеріалу, 
який сам по собі ще не забезпечує граматично адекватного їх вживання.

Серед мовних вправ найбільш продуктивними $\epsilon$ ті, що побудовані на синтаксичних одиницях і текстах, а не на окремих словах. Мовні вправи сприяють готовності до граматично правильного говоріння й письма, але не формують мовленнєву діяльність, тому необхідне введення таких вправ у практику навчання дітей, щоб, за М.С. Вашуленком, граматичні вміння змогли перерости у відповідну навичку (Вашуленко, 2019).

Аналізуючи розділ «Будова слова», ми акцентуємо на змісті та співвідношенні аналітичних і синтетичних завдань у фактичному матеріалі підручників, їх систематизації та на тому, наскільки ефективно вони сприяють розв'язанню завдань цього розділу.

Аналіз вправ розділу «Будова слова» продемонструємо в таблиці 1.1.

Відповідно до даних таблиці у підручнику переважають аналітико-синтетичні вправи (69\%). Аналітичні вправи в середньому становлять $23 \%$ усіх вправ, та найменше - синтетичних вправ. Цей факт не можна визнати спри- ятливим для продуктивного переносу мовних теоретичних знань на практику. Приділяючи багато часу аналізу і не надаючи належного значення синтетичним завданням, ми певною мірою затримуємо формування в учнів практичних навичок і вмінь.

Для формування навичок і вмінь необхідно добирати багато вправ, які мають бути взаємозумовлені та систематизовані, де б одна вправа або група однотипних вправ могли підготувати учня до виконання наступних завдань, в яких має бути враховано матеріал, відпрацьований попередніми вправами. Мовленнєві вміння формуються поетапно:

І етап - знання (усвідомлення);

П етап - первісні вміння;

Ш етап - навички.

Процес розуміння предметів та явищ об'єктивної дійсності, утворення про них наукових понять - складний і багатоплановий. У розумових діях можна виокремити їх головні складові елементи, або процеси - розумові операції. Такими є порівняння, аналіз, синтез, абстрагування, узагальнення, класифікація, систематизація.

Таблиця 1.1.

Аналіз вправ розділу «Будова слова»

\begin{tabular}{|c|c|c|c|c|}
\hline \multirow{2}{*}{$\begin{array}{c}\text { № } \\
\text { ПI/II }\end{array}$} & \multirow[b]{2}{*}{ Тема } & \multicolumn{3}{|c|}{ Кількість вправ } \\
\hline & & аналітичні & синтетичні & $\begin{array}{l}\text { аналітико- } \\
\text { синтетичні }\end{array}$ \\
\hline 1. & Закінчення слова & 2 & 1 & 6 \\
\hline 2. & Основа слова & 2 & - & 5 \\
\hline 3. & Частини основи: корінь, префікс, суфікс & 3 & - & 9 \\
\hline 4. & Споріднені (спільнокореневі) слова. Корінь & 3 & 2 & 7 \\
\hline 5. & Чергування голосних і приголосних звуків у коренях слів & 1 & - & 4 \\
\hline 6. & $\begin{array}{c}\text { Вимова і правопис слів із } \\
\text { наголошеними [e], [и] в коренях }\end{array}$ & 1 & 1 & 5 \\
\hline 7. & $\begin{array}{c}\text { Наголошені [е], [и], які } \\
\text { перевіряються наголосом }\end{array}$ & 2 & 1 & 7 \\
\hline 8. & $\begin{array}{c}\text { Ненаголошені [e], [и], які } \\
\text { не перевіряються наголосом }\end{array}$ & 2 & - & 8 \\
\hline 9. & $\begin{array}{c}\text { Вимова і правопис слів із } \\
\text { дзвінкими та глухими } \\
\text { приголосними звуками }\end{array}$ & 2 & 2 & 7 \\
\hline 10. & Префікс & 2 & 1 & 8 \\
\hline 11. & Префікси і прийменники & 2 & 1 & 7 \\
\hline 12. & Правопис префіксів роз-, без & 2 & - & 8 \\
\hline 13. & Вимова і правопис префікса з- (с-) & 2 & 1 & 9 \\
\hline 14. & Апостроф після префіксів & 3 & - & 5 \\
\hline 15. & Суфікс & 3 & 1 & 8 \\
\hline & Загалом вправ & $\begin{array}{l}32 \text { вправи } \\
(23 \%)\end{array}$ & $\begin{array}{l}11 \text { вправ } \\
(8 \%)\end{array}$ & $\begin{array}{l}103 \text { вправи } \\
(69 \%)\end{array}$ \\
\hline
\end{tabular}


Аналіз завдань, спрямованих на розвиток мислення учнів 3-4 класів, засвідчив таке їх кількісне співвідношення: порівняння -3 , аналогія -11 , виділення головного - 0 , узагальнення -4 , систематизація -6 , конкретизація -1 , абстрагування - 4. Як бачимо, найбільша кількість вправ на аналогію і узагальнення та систематизацію, найменша - завдання на розвиток абстрагування і конкретизації, відсутні вправи на виділення головного.

Виникає потреба в розробленні такої системи вправ, яка б забезпечувала реалізацію зазначеної лінії змісту навчання української мови та читання в початкових класах. На нашу думку, доцільно було б при створенні системи завдань забезпечити оптимальне кількісне співвідношення вправ аналітичного й синтетичного характеру, що має підпорядковуватися вимогам практичного формування граматичних навичок і вмінь, тобто обсяг синтетичних завдань має перевищувати обсяг аналітичних, тому що в спеціальному навчанні мови система завдань, яка не формує навичок і вмінь, недоцільна.

3 метою з'ясування стану реалізації мовної змістової лінії під час вивчення розділу «Будова слова» нами було проведено опитування 115 учителів початкових класів м. Рівне та Рівненської області.

На перше питання «На які підходи орієнтують типові освітні програми і зорієнтовані на них підручники «Украӥнська мова та читання?» $72,8 \%$ учителів відповіли індиферентно. Складалося враження, що вони не знають підходів, на які зорієнтовані чинні освітні програми і підручники української мови та читання для початкових класів. Дехто називав системномовний підхід, дехто - комунікативний, а деякі вчителі писали, що хочуть, аби в підручниках більше було диференційованих завдань і вправ ігрового та творчого характеру, а 27,2\% зовсім не дали відповіді на запитання. Відповіді на це питання засвідчили, що в системі педагогічної роботи вчителів комунікативно-діяльнісний підхід не завжди посідає належне місце i навчання часто перетворюється на нецікаве і незрозуміле для дітей заучування граматичних понять.

На питання «Як Ви вважаєте, чи достатня кількість вправ для вивчення будови слова y чинних підручниках української мови та читання для 3-4 класів? Чи доиільно викла- дений у них навчальний матеріал щзодо будови слова?» 45,5\% учителів вважають, що в підручниках вправ і завдань для вивчення будови слова вистачає, доцільно викладений матеріал у чинних підручниках. Пропозицій щодо зміни структури розділу чи раціональності використаних вправ від учителів не поступило.

На питання «Як часто Ви використовуєте пояснення морфемної будови слова на уроках украӥнської мови, де теми не стосуються будови слова?» ми отримали такі відповіді : часто - 36,4\%, індиферентно - 54,5\%, не дали відповіді - 9,1\%.

На питання «Коли $i$ з якою метою звертаєтеся на уроках украӥнської мови до питання морфемної будови слова?» вчителі відповіли: в орфографічній роботі з окремими словами $91,1 \%$, у словниковій (лексичній) роботі - 100\%, щоб поглибити знання й інтелект учнів $-36,4 \%$, щоб викликати інтерес до рідного слова - 79\%.

Анкетування засвідчило, що всі вчителі $(100 \%)$ вважають роботу над морфемною будовою слова важливою, визнають іiі ефективність у формуванні пізнавального інтересу до рідного слова, а також як засобу поглиблення інтелекту молодших школярів.

I хоч $36,4 \%$ вчителів пояснюють структуру слова на уроках української мови, де теми пов'язані з іншим мовним матеріалом і не стосуються будови слова, зіставлення їхніх відповідей з іншими показниками анкети, а також спостереження уроків показали, що з'ясовують будову слова вони нечасто. Отже, отримані нами результати переконують, що вчителі початкових класів приділяють мало уваги морфемній будові слова на уроках української мови та читання.

Висновки i перспективи дослідження. Постійний інтерес науковців, методистів та вчителів-практиків до вивчення розділу «Будова слова» у початковій школі, розвивальних можливостей уроків мови під час опанування учнями структури слова свідчить про важливість цього розділу в системі української мови початкового навчання.

У результаті реалізації змістової лінії «Досліджуємо мовні явища» в процесі вивчення розділу «Будова слова» учні початкових класів оволодівають способом розкриття лексичного значення слів, розуміють основні джерела поповнення української мови новими словами, 
усвідомлюють роль морфем у слові, їх значення, що формує точність мовлення, виробляють навички правопису морфем слова, розвивають розумові здібності та вміння.

Перспективним i практично значущим $\epsilon$ таке вивчення морфемної будови слова, яке $б$ якнайповніше забезпечувало широкий вихід отриманих учнями мовних знань у їхню мовленнєву практику. Саме на це й спрямовані чинні програми для початкової школи, в яких підкреслюється не тільки необхідність формувати в молодших школярів уміння членувати слова на значущі частини (морфеми), а й наголошується на потребі ширше використовувати наявні можливості для мовленнєвого розвитку дітей, зокрема для збагачення їхнього словникового запасу похідними лексемами, їхнього інтелектуального розвитку.

\section{ЛІТЕРАТУРА:}

1. Бісовецька Л. Комплексний підхід до вивчення слова під час опрацювання теми «Будова слова» в початковій школі. Науковий вісник Східноєвропейського наиіонального університету імені Лесі Украйнки. Педагогічні науки. 2016. Випуск 1(1). С. 28-33.

2. Вашуленко М. Нова українська школа : методика навчання інтегрованого курсу «Українська мова» у 1-2 класах закладів загальної середньої освіти на засадах компетентнісного підходу : навч. метод. посібник. Київ : Видавничий дім «Освіта», 2019. 192 с.

3. Вашуленко М., Васильківська Н., Дубовик С.Українська мова та читання. Підручник для 3 класу закладів загальної середньої освіти. Частина 1. Київ : Видавничий дім «Освіта», 2020. 160 с.

4. Вашуленко М., Васильківська Н., Дубовик С.Українська мова та читання. Підручник для 4 класу закладів загальної середньої освіти. Частина 1. Київ : Видавничий дім «Освіта», 2020. 168 с.

5. Вашуленко М., Дубовик С. Формування в учнів початкових класів дослідницьких умінь на матеріалі програмового курсу української мови. Початкова школа. 2020. № 3. С. 11-17.

6. Гордієнко О. Розвивальна спрямованість уроків вивчення будови слова в початкових класах. Наукові записки Ніжсинського державного університету ім. М. Гоголя. 2014. № 3. С. 151-155.

7. Гриненко О.М. Формування знань про будову слова у молодших школярів 3 тяжкими порушеннями мовлення : автореф. дис. ... канд. пед. наук : 13.00 .03 «Корекційна педагогіка». Київ, 2014. 20 с.

8. Державний стандарт початкової загальної освіти. URL: http://dano.dp.ua/attachments/article/303/ Державний\%20стандарт\%20початкової\%20 освіти. pdf.

9. 9.Пономарьова К. Реалізація змістових ліній початкового курсу мовно-літературної освіти в 2-му класі. URL: https://lib.iitta.gov.ua >.

10. Типові освітні програми для закладів загальної середньої освіти: 1-2 та 3-4 класи. Київ : Видавництво «Світоч», 2019. 336.

\section{REFERENCES:}

1. Bisovetska L. (2016). Kompleksnyi pidkhid do vyvchennia slova pid chas opratsiuvannia temy «Budova slova» v pochatkovii shkoli [A comprehensive approach to the studyof the word during the study of the topic «Word structure» in primary school]. Naukovyi visnyk Skhidnoievropeiskoho natsionalnoho universytetu imeni Lesi Ukrainky. Pedahohichni nauky. Vypusk 1(1). P. 28-33 [in Ukrainian].

2. Vashulenko M. (2019). Nova ukrainska shkola: metodyka navchannia intehrovanoho kursu «Ukrainska mova» u 1-2 klasakh zakladiv zahalnoi serednoi osvity na zasadakh kompetentnisnoho pidkhodu [New Ukrainian school: methods of teaching an integrated course «Ukrainian language» in 1-2 grades of general secondary education on the basis of a competency approach]: navch. metod.posibnyk. Kyiv. Vydavnychyidim «Osvita», 192 p. [in Ukrainian].

3. Vashulenko M., Vasylkivska N., Dubovyk S. (2020) Ukrainska mova ta chytannia [Ukrainian and reading]. Pidruchnyk dlia 3 klasu zakladiv zahalnoi serednoi osvity Chastyna 1. Kyiv. Vydavnychyi dim «Osvita», 160 p. [in Ukrainian].

4. Vashulenko M., Vasylkivska N., Dubovyk S.Ukrainska mova ta chytannia (2021) [Ukrainian and reading]. Pidruchnyk dlia 4 klasu zakladiv zahalnoi serednoi osvity. Chastyna 1. Kyiv. Vydavnychyi dim «Osvita». 168 p. [in Ukrainian].

5. Vashulenko M., Dubovyk S.(2020). Formuvannia v uchniv pochatkovykh klasiv doslidnytskykh umin na materiali prohramovoho kursu ukrainskoi movy. [Formation of initial classes of research skills on the material of the program of Ukrainian language]. Pochatkova shkola, № 3. P. 11-17.

6. Hordiienko O. (2014). Rozvyvalna spriamovanist urokiv vyvchennia budovy slova v pochatkovykh klasakh [A developing orientation of lessons of study of structure of word is in initial classes]. Naukovi zapysky Nizhynskoho derzhavnoho universytetu im. M. Hoholia. № 3. P. 151-155 [in Ukrainian]. 
7. Hrynenko O. (2014). Formuvannia znan pro budovu slova u molodshykh shkoliariv z tiazhkymy porushenniamy movlennia [Forming of knowledge about the structure of word for junior schoolchildren with heavy violations of broadc asting]. Avtoref. Dys. ... kand. ped. nauk. 13.00 .03 «korektsiina pedahohika». Kyiv, 20 p. [in Ukrainian].

8. Derzhavnyi standart pochatkovoi zahalnoi osvity [State standard of primary general education] URL: http://dano.dp.ua/attachments/article/303/Derzhavnyi\%20standart\%20pochatkovoi\%2 0osvity.pdf.

9. Ponomarova K. (2019). Realizatsiia zmistovykh linii pochatkovoho kursu movnoliteraturnoi osvity v 2-mu klasi [Implementation of the content lines of the initial course of language-literary education in the 2nd grade]. URL: https://lib.iitta.gov.ua >.

10. Typovi osvitni prohramy dlia zakladiv zahalnoi serednoi osvity:1-2 ta 3-4 klasy (2019) [Typical educational programs for general secondary education institutions: 1-2 and 3-4 classes]. Kyiv: Vydavnytstvo «Svitoch». $336 \mathrm{~s}$. [in Ukrainian]. 